\title{
Analisis Pemborosan Waktu Produksi Pada Bagian Perakitan Rumah Boneka Menggunakan Pendekatan Lean
}

\author{
Tiara $^{1}$, Surya Perdana ${ }^{2}$ \\ 1,2Program Studi Teknik Industri, Universitas Indraprasta PGRI \\ 1tiaramardi.04@@gmail.com \\ ${ }^{2}$ suryaperdana.st.mm@gmail.com
}

\begin{abstract}
Abstrak
$\mathrm{CV}$. RB yang menjadi objek penelitian ini merupakan perusahaan industri manufaktur produksi rumah boneka yang berbahan dasar kayu. Tujuan penelitian ini adalah untuk mengevaluasi pemborosan (waste) dan memberikan usulan perbaikan proses produksi sehingga dapat meningkatkan efisiensi waktu produksi pada CV. RB. Sistem produksi lean memberikan suatu perubahan yang baik pada perusahaan. Dalam menyelesaikan permasalahan yang sedang dihadapi maka analisa yang dilakukan dalam penelitian ini adalah analisis NVA dan NVAN menggunakan fishbone diagram teknik analisa data pada penelitian ini dilihat dari segi NVA dan NVAN. Pada proses perakitan pola terdapat 27 aktivitas pekerja, dimulai dari perakitan lantai dasar ke bagian kiri sampai dengan pemasangan genteng pada bagian kanan. berdasarkan klasifikasi VA, NVA dan NVAN pada proses pengamplasan, terlihat bahwa terjadi 30 waste pada klasifikasi NVA dengan persentasi waktu 19,2\%, terjadi 18 waste pada klasifikasi NVAN dengan persentasi waktu $0,6 \%$. Berdasarkan pengamatan di lantai produksi terdapat pemborosan waktu pada proses pengerjaan perakitan pola. Hal ini disebabkan oleh beberapa faktor yaitu: material, manusia, lingkungan dan mesin. Beberapa pemborosan waktu produksi proses perakitan pola yang mengakibatkan lamanya kegiatan. pemborosan yang terdapat pada bagian perakitan ini yaitu motion dan waiting.
\end{abstract}

Kata kunci: Waste, Lean, NVA, NVAN

\begin{abstract}
$C V . R B$ which is the object of this research is a manufacturing company producing wood-based doll houses. The purpose of this study is to evaluate waste and provide recommendations for improving the production process so that it can improve the efficiency of production time on the $C V$. RB. The lean production system gives a good change to the company. In solving the problems that are being faced, the analysis carried out in this study is the analysis of NVA and NVAN using fishbone diagram data analysis techniques in this study in terms of NVA and NVAN. In the process of assembling the pattern there are 27 worker activities, starting from the ground floor assembly to the left to the installation of tile on the right. based on the VA, NVA and NVAN classification in the sanding process, it can be seen that there are 30 wastes in the NVA classification with a percentage of time of $19.2 \%$, there are 18 wastes in the NVAN classification with a percentage time of $0.6 \%$. Based on observations on the production floor there is a waste of time in the process of assembling the pattern. This is caused by several factors, namely: material, human, environment and machinery. Some waste of production time is a pattern assembly process that results in long activities. waste contained in this assembly part is motion and waiting.
\end{abstract}

Keywords: Waste, Lean, NVA, NVAN

\section{PENDAHULUAN}

Industri Mikro dan Kecil (IMK) merupakan kekuatan strategis dan penting untuk mempercepat pembangunan daerah. Sektor ini terbukti memberikan kontribusi signifikan terhadap PDB (Pendapatan Domestik Bruto) dan penyerapan tenaga kerja. Di samping itu, IMK memiliki posisi penting dalam hal pemerataan kesejahteraan masyarakat di daerah dan mengurangi kesenjangan (gap) pendapatan [1]. 
CV. RB sebagai objek dalam penelitian ini merupakan IMK yang bergerak dalam industri manufaktur produksi rumah boneka yang berbahan dasar kayu. Produksi rumah boneka pada CV. RB dikerjakan oleh beberapa pekerja yang sebagian besar berkebutuhan khusus. Hal tersebut menjadi tantangan bagi CV. RB dan para pekerjanya dalam menjalankan usahanya. Dengan keterbatasan yang dimiliki oleh para pekerjanya CV. RB tetap harus menjaga kualitas produk yang dihasilkan memenuhi standar perusahaan dan keinginan konsumen.

Teknik yang digunakan CV. RB untuk memproduksi rumah boneka ini masih sederhana, yaitu dengan menggunakan peralatan manual, beberapa mesin yang digunakan untuk proses produksi yaitu, mesin potong, bor dan amplas. Banyak pemborosan yang terjadi di perusahaan akan memberikan pengaruh kepada konsumen diantaranya ketertundaan pengiriman pesanan rumah boneka kepada konsumen dan penyusunan bahan dan alat yang tidak teratur. Menerapkan Lean untuk merancang aliran proses dengan cara penghapusan akar penyebab limbah kemudian melakukan perbaikan proses produksi [2].

Sistem produksi lean memberikan suatu perubahan yang baik pada perusahaan. Lean digunakan untuk mengubah Industri kecil dan menengah (IKM) menjadi ramping [3]. Tujuan penelitian ini adalah untuk mengevaluasi pemborosan (waste) dan memberikan usulan perbaikan proses produksi sehingga dapat meningkatkan efisiensi waktu produksi pada CV. RB.

\section{METODE PENELITIAN}

Data yang dikumpulkan dalam penelitian ini adalah data waktu proses produksi rumah boneka, foto dan elemen pekerjaan masing-masing stasiun kerja, komponen rumah boneka, alat dan bahan produksi rumah boneka. Penelitian ini berfokus pada waktu proses produksi CV. RB dan elemen pekerjaan masingmasing stasiun kerja. dalam penelitian ini hanya dipilih responden yang mengetahui tentang proses produksi. Informasi yang dikumpulkan pada penelitian ini adalah terkait profil CV. RB.

Dalam hal ini penelitian akan melakukan observasi selama pekerja melakukan aktivitas pembuatan rumah boneka. Observasi ini dilakukan untuk memperoleh waktu kerja proses perakitan dan mengetahui jenis pemborosan yang terjadi pada CV. RB.

Wawancara dilakukan kepada pekerja yang melakukan aktivitas pembuatan rumah boneka dengan manajer wisma CV. RB tersebut. Pertanyaan yang diajukan kepada pekerja dan manajer wisma CV. RB adalah mengenai proses produksi rumah boneka pada proses perakitan, jam kerja pekerja dalam satu hari, jumlah pekerja dalam produksi rumah boneka, alat dan bahan yang digunakan pada proses produksi rumah boneka dan kendala masing-masing pekerja.

Dalam menyelesaikan permasalahan yang sedang dihadapi maka analisa yang dilakukan dalam penelitian ini adalah analisis NVA dan NVAN menggunakan fishbone diagram teknik analisa data pada penelitian ini dilihat dari segi NVA dan NVAN. NVA adalah suatu aktivitas yang tidak memberikan nilai tambah bagi konsumen akhir, pada klasifikasi ini terdapat waste yang mengakibatkan panjangnya lead time pada produksi rumah boneka dan juga mengakibatkan keterlambatan pengiriman barang kepada konsumen [4].

Sedangkan NVAN adalah suatu aktivitas yang tidak memberikan nilai tambah kepada konsumen, tetapi aktivitasnya diperlukan dalam proses produksi. Kedua klasifikasi ini harus dihilangkan dari proses produksi untuk mendapatkan waktu yang maksimal. Kelompok NVAN, meskipun tidak harus segera, sebisa mungkin dikurangi atau dihilangkan sedangkan NVA harus segera diprioritaskan untuk dihilangkan [4].

Fishbone diagram digunakan untuk mengidentifikasi berbagai sebab potensial dari satu efek atau masalah yang terjadi pada produksi rumah boneka, dan menganalisis masalah tersebut melalui sesi brainstorming. Masalah akan dipecah menjadi sejumlah kategori yang berkaitan, mencakup manusia, material, mesin dan lingkungan. 
Setelah menggambarkan dan menganalisa fishbone diagram, maka langkah selanjutnya menganalisis faktor-faktor penyebab masalah dari fishbone diagram, kemudian melakukan pertanyaan "mengapa" masalah tersebut terjadi pada masing-masing faktor tersebut. Sampai mendapatkan akar masalah yang paling utama dari faktor tersebut. Setelah melakukan analisis 5 why, maka langkah selanjutnya adalah mencari usulan perbaikan bersama dengan tim produksi CV.RB dari akar masalah tersebut.

\section{HASIL DAN PEMBAHASAN}

Pada proses perakitan pola terdapat 27 aktivitas pekerja, dimulai dari perakitan lantai dasar ke bagian kiri sampai dengan pemasangan genteng pada bagian kanan. Semua aktivitas perakitan tersebut dapat dilihat pada Gambar 1.
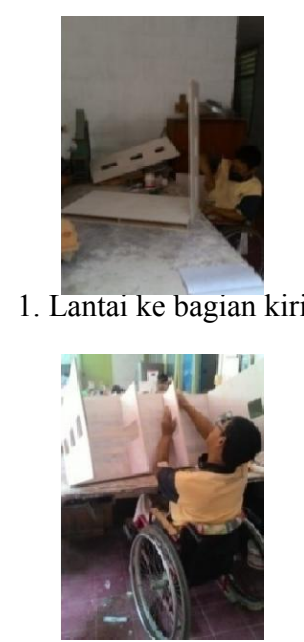

5. Sekat pada lantai kedua
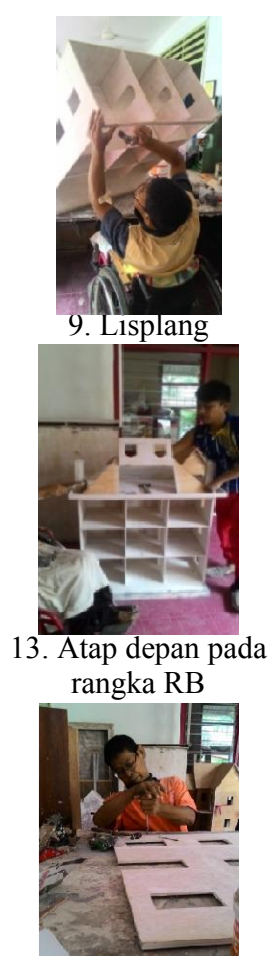

17.Engsel bagian depan
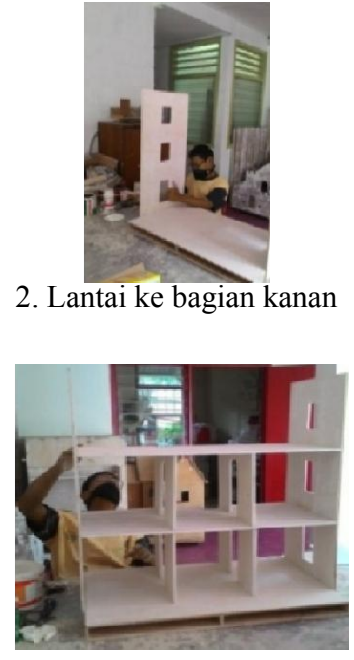

6. Lantai ketiga

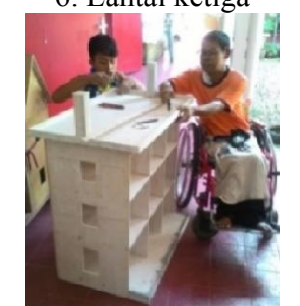

10. Atap atas pada rangka

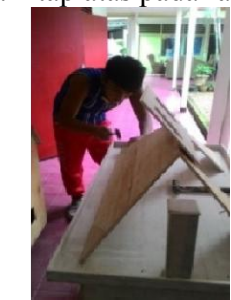

14. Atap belakang pada

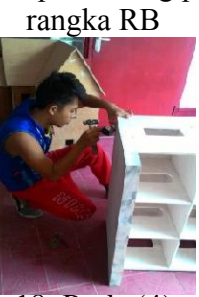

18. Roda (4)

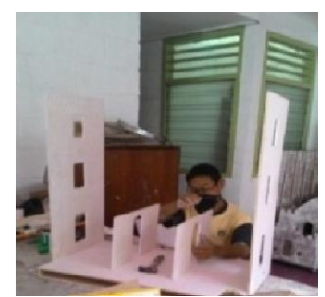

3. Sekat pada lantai dasar

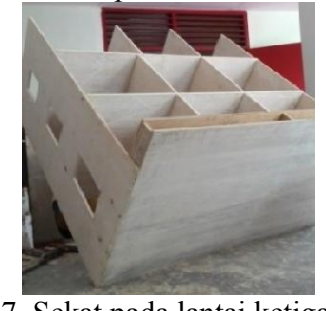

7. Sekat pada lantai ketiga

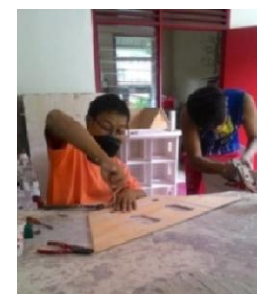

11. Engsel pada atap depan

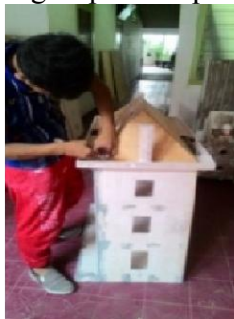

15. Atap kiri

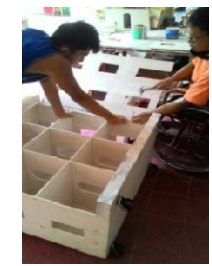

19. Bagian depan

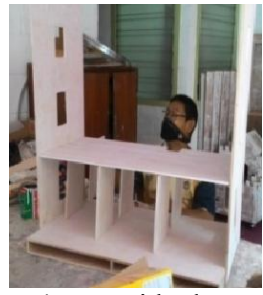

4. Lantai kedua
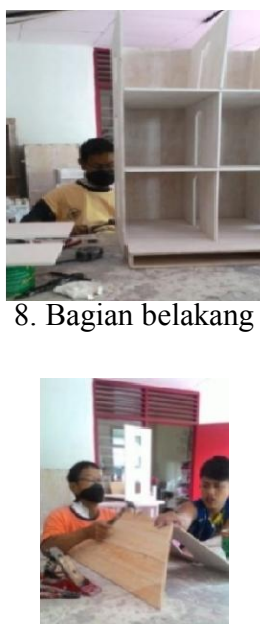

12. Atap depan ke atap

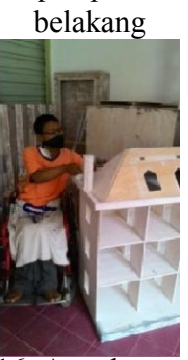

16. Atap kanan

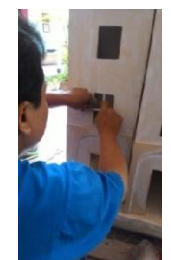

20. Silang Jendela 


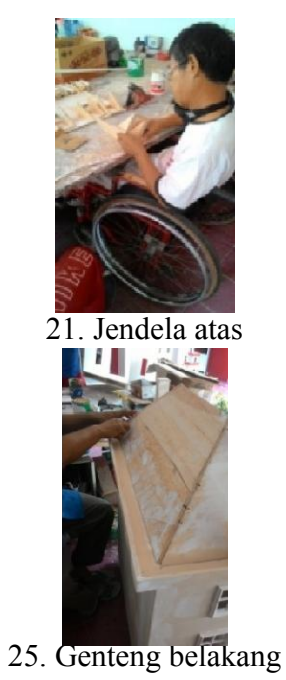

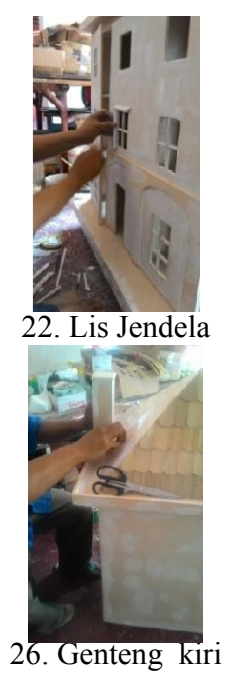
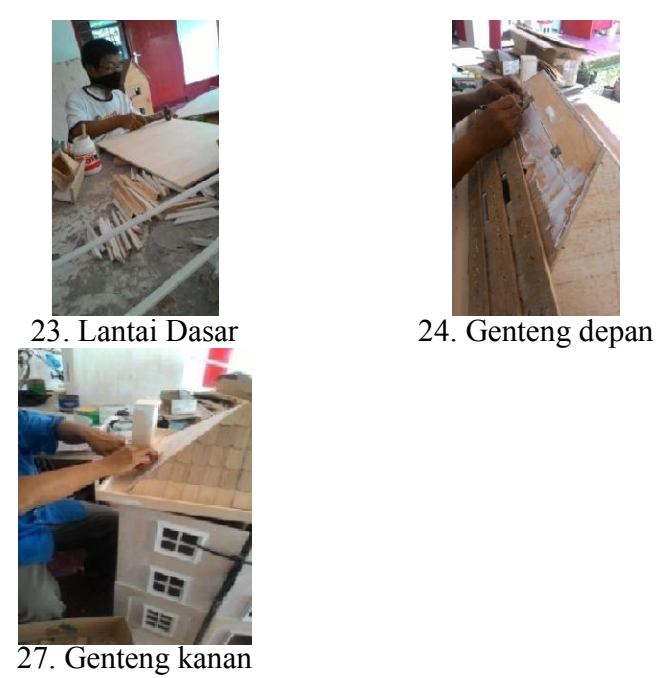

Gambar 1. Proses Perakitan

Setelah dilakukan pengambilan foto dan perhitungan waktu produksi selama 3 kali pengamatan dari masing-masing elemen pekerjaan pada setiap aktivitas pembuatan pola, langkah selanjutnya adalah merekapitulasi waktu produksi dari elemen pekerjaan pertama sampai elemen pekerjaan terakhir. Rekapitulasi waktu proses produksi perakitan dapat dilihat pada Tabel 2.

Tabel 2. Rekapitulasi Waktu Proses Produksi Pada Proses Perakitan Selama 3 Kali Pengamatan

\begin{tabular}{lcccc}
\hline \multicolumn{1}{c}{ Elemen Pekerjaan } & $\begin{array}{c}\text { Pengamatan } \\
\text { ke-1 } \\
\text { (Menit) }\end{array}$ & $\begin{array}{c}\text { Pengamatan } \\
\text { ke-2 } \\
\text { (Menit) }\end{array}$ & $\begin{array}{c}\text { Pengamatan } \\
\text { ke-3 } \\
\text { (Menit) }\end{array}$ & $\begin{array}{c}\text { Rata- } \\
\text { rata } \\
\text { (Menit) }\end{array}$ \\
\hline Lantai ke bagian kiri & 11,08 & 10,95 & 11,06 & 11,03 \\
\hline Lantai ke bagian kanan & 10,95 & 11,15 & 10,98 & 11,02 \\
\hline Sekat ke lantai dasar (2) & 16,06 & 15,92 & 16,12 & 16,03 \\
\hline Lantai kedua & 7,12 & 7,18 & 7,15 & 7,2 \\
\hline Sekat pada lantai kedua (2) & 19,12 & 18,92 & 19,13 & 19,1 \\
\hline Lantai ketiga & 11,05 & 10,95 & 11,15 & 11,05 \\
\hline Sekat pada lantai ketiga (2) & 26,27 & 26,2 & 26,32 & 26,3 \\
\hline Bagian belakang & 21,3 & 21,25 & 20,75 & 21,1 \\
\hline Lisplang & 5,45 & 5,87 & 5,98 & 5,8 \\
\hline Atap atas pada rangka RB & 15,22 & 15,12 & 16,48 & 15,6 \\
\hline Engsel pada atap depan & 12,26 & 12,08 & 12,52 & 12,3 \\
\hline Atap depan ke atap belakang & 7,28 & 7,27 & 6,97 & 7,2 \\
\hline Atap depan pada rangka RB & 5,02 & 5,25 & 5,15 & 5,14 \\
\hline Atap belakang rangka RB & 5,45 & 5,4 & 5,32 & 5,4 \\
\hline Atap kiri & 10,88 & 11,25 & 11,33 & 11,2 \\
\hline Atap kanan & 11,21 & 10,86 & 10,83 & 11 \\
\hline Engsel pada bagian depan & 15,35 & 15,78 & 15,58 & 15,6 \\
\hline Roda (4) & 16,43 & 16,37 & 16,03 & 16,3 \\
\hline Lis jendela (16) & 60,42 & 59,76 & 60,15 & 60,1 \\
\hline Bagian depan & 13,18 & 13,05 & 13,2 & 13,1 \\
\hline Silang jendela (16) & 62,17 & 59,76 & 61,25 & 61,1 \\
\hline Jendela atas (2) & 13,05 & 13,2 & 12,87 & 13,04 \\
\hline Genteng depan & 60,15 & 60,25 & 59,76 & 60,1 \\
\hline Genteng belakang & 55,35 & 55,83 & 55,42 & 55,5 \\
\hline Genteng kiri & 31,95 & 31,9 & 32,12 & 31,9 \\
\hline Genteng kanan & 33,17 & 32,92 & 33,12 & 33,1 \\
\hline & & & & $\mathbf{5 6 9 , 0 1}$ \\
\hline
\end{tabular}


Selanjutnya identifikasi waste pada proses perakitan, pada proses perakitan ini terdapat 78 pekerjaan, kemudian ditentukan dari masing-masing pekerjaan tersebut yang termasuk klasifikasi VA, NVA atau NVAN. Kemudian dari masing-masing klasifikasi tersebut dapat dihitung persentasi waktu kerjanya. Identifikasi waste pada proses perakitan dapat dilihat pada Tabel 3.

Tabel 3. Proses Identifikasi Waste Perakitan Pola

\begin{tabular}{|c|c|c|c|c|c|c|}
\hline \multirow{2}{*}{ No } & \multirow{2}{*}{$\begin{array}{c}\text { Elemen } \\
\text { Pekerjaan }\end{array}$} & \multirow{2}{*}{$\begin{array}{l}\text { Waktu } \\
\text { (Menit) }\end{array}$} & \multirow{2}{*}{ Ket. Waste } & \multicolumn{3}{|c|}{ Klasifikasi } \\
\hline & & & & VA & NVA & NVAN \\
\hline \multirow{3}{*}{1} & \multirow{3}{*}{$\begin{array}{l}\text { Lantai ke } \\
\text { bagian kiri }\end{array}$} & 1.11 & Memindahkan bahan dari bengkel & & $\sqrt{ }$ & \\
\hline & & 0,33 & Mencari alat & & & $\sqrt{ }$ \\
\hline & & 11 & Perakitan pola & $\sqrt{ }$ & & \\
\hline \multirow{3}{*}{2} & \multirow{3}{*}{$\begin{array}{c}\text { Lantai ke } \\
\text { bagian kanan }\end{array}$} & 1,11 & Memindahkan bahan dari bengkel & & $\sqrt{ }$ & \\
\hline & & 0,16 & Mengambil paku & & & $\sqrt{ }$ \\
\hline & & 11 & Perakitan pola & $\sqrt{ }$ & & \\
\hline \multirow{3}{*}{3} & \multirow{3}{*}{$\begin{array}{l}\text { Sekat pada } \\
\text { lantai dasar } \\
\text { (2) }\end{array}$} & 1,11 & Memindahkan bahan dari bengkel & & $\sqrt{ }$ & \\
\hline & & 5 & Mengulang kembali proses perakitan & & $\sqrt{ }$ & \\
\hline & & 16 & Perakitan pola & $\sqrt{ }$ & & \\
\hline \multirow{3}{*}{4} & \multirow{3}{*}{ Lantai kedua } & 1,16 & Memindahkan bahan dari bengkel & & $\sqrt{ }$ & \\
\hline & & 0,15 & Mengambil alat dan paku & & & $\sqrt{ }$ \\
\hline & & 7 & Perakitan pola & $\sqrt{ }$ & & \\
\hline \multirow{3}{*}{5} & \multirow{3}{*}{$\begin{array}{l}\text { Sekat pada } \\
\text { lantai kedua } \\
\text { (2) }\end{array}$} & 1,16 & Memindahkan bahan dari bengkel & & $\sqrt{ }$ & \\
\hline & & 0,1 & Mengambil bahan dan alat & & & $\sqrt{ }$ \\
\hline & & 19 & Perakitan pola & $\sqrt{ }$ & & \\
\hline \multirow{2}{*}{6} & \multirow{2}{*}{ Lantai ketiga } & 1,11 & Memindahkan bahan dari bengkel & & $\sqrt{ }$ & \\
\hline & & 11 & Perakitan pola & $\sqrt{ }$ & & \\
\hline \multirow{4}{*}{7} & \multirow{4}{*}{$\begin{array}{l}\text { Sekat pada } \\
\text { lantai ketiga } \\
\text { (2) }\end{array}$} & 4 & Mengulang kembali proses perakitan & & $\sqrt{ }$ & \\
\hline & & 1,11 & Memindahkan bahan dari bengkel & & $\sqrt{ }$ & \\
\hline & & 26 & Perakitan pola & $\sqrt{ }$ & & \\
\hline & & 3 & Mengulang kembali proses perakitan & & $\sqrt{ }$ & \\
\hline \multirow{3}{*}{8} & \multirow{3}{*}{$\begin{array}{c}\text { Bagian } \\
\text { belakang }\end{array}$} & 0,96 & Memindahkan bahan dari bengkel & & $\sqrt{ }$ & \\
\hline & & 0,6 & Memilih paku yang tidak berkarat & & & $\sqrt{ }$ \\
\hline & & 21 & Perakitan pola & $\sqrt{ }$ & & \\
\hline & & 0,96 & Memindahkan bahan dari bengkel & & $\sqrt{ }$ & \\
\hline 9 & Lisplang & 5 & Perakitan pola & $\sqrt{ }$ & & \\
\hline & & 5 & Menunggu Proses pengeringan pada lisplang & & $\sqrt{ }$ & \\
\hline 10 & Atap atas pada & 0,58 & Memindahkan bahan dari bengkel & & $\sqrt{ }$ & \\
\hline & & 15 & Perakitan pola & $\sqrt{ }$ & & \\
\hline 11 & $\begin{array}{l}\text { Engsel pada } \\
\text { atap depan }\end{array}$ & 2 & Mengulang kembali proses perakitan & & $\sqrt{ }$ & \\
\hline & & 0,25 & Mengambil bahan dan alat & & & $\sqrt{ }$ \\
\hline & Atap depan ke & 12 & Perakitan & $\sqrt{ }$ & & \\
\hline 12 & atap belakang & 0,08 & Mengambil bahan dan alat & & & $\sqrt{ }$ \\
\hline & & 7 & Perakitan & $\sqrt{ }$ & & \\
\hline & & 7 & $\begin{array}{l}\text { Menunggu proses pengeringan pada proses } \\
\text { sebelumnya }\end{array}$ & & $\sqrt{ }$ & \\
\hline 13 & $\begin{array}{l}\text { Atap depan } \\
\text { pada rangka }\end{array}$ & 1 & $\begin{array}{l}\text { Mengukur jarak tepi Rangka rumah boneka untuk } \\
\text { perakitan atap depan }\end{array}$ & $\sqrt{ }$ & & \\
\hline & & 6 & Perakitan & $\sqrt{ }$ & & \\
\hline & & 0,13 & Mengambil bahan dan alat & & & $\sqrt{ }$ \\
\hline 14 & $\begin{array}{l}\text { Atap belakang } \\
\text { pada rangka }\end{array}$ & 0,5 & $\begin{array}{c}\text { Mengukur jarak antara atap depan ke atap } \\
\text { belakang }\end{array}$ & & & $\sqrt{ }$ \\
\hline & & 5 & Perakitan & $\sqrt{ }$ & & \\
\hline & & 0,5 & Memindahkan bahan dari bengkel & & $\sqrt{ }$ & \\
\hline 15 & Atap kiri & 0,83 & $\begin{array}{l}\text { Salah dalam proses pemotongan (bagian atap } \\
\text { yang kurang dalam penyerutannya }\end{array}$ & & $\sqrt{ }$ & \\
\hline & & 11 & Perakitan & $\sqrt{ }$ & & \\
\hline & & 0,5 & Memindahkan bahan dari bengkel & & $\sqrt{ }$ & \\
\hline 16 & Atap kanan & 0,6 & $\begin{array}{l}\text { Salah dalam proses pemotongan (bagian atap } \\
\text { yang kurang dalam penyerutannya) }\end{array}$ & & $\sqrt{ }$ & \\
\hline & & 11 & Perakitan & $\sqrt{ }$ & & \\
\hline & Engsel bagian & 0,16 & Mengambil bahan dan alat & & & $\sqrt{ }$ \\
\hline 17 & depan & 0,1 & Mengukur jarak engsel & $\sqrt{ }$ & & \\
\hline
\end{tabular}




\begin{tabular}{|c|c|c|c|c|c|c|}
\hline \multirow{3}{*}{ No } & \multirow{3}{*}{$\begin{array}{c}\text { Elemen } \\
\text { Pekerjaan }\end{array}$} & \multirow{3}{*}{$\begin{array}{c}15 \\
\text { Waktu } \\
\text { (Menit) }\end{array}$} & \multirow{3}{*}{$\begin{array}{l}\text { Perakitan } \\
\text { Ket. Waste }\end{array}$} & \multirow{2}{*}{\multicolumn{3}{|c|}{ Klasifikasi }} \\
\hline & & & & & & \\
\hline & & & & VA & NVA & NVAN \\
\hline \multirow{3}{*}{18} & \multirow{3}{*}{ Roda (4) } & 0,11 & Mengambil bahan dan alat & & & $\sqrt{ }$ \\
\hline & & 0,2 & Mengukur & $\sqrt{ }$ & & \\
\hline & & 16 & Perakitan & $\sqrt{ }$ & & \\
\hline \multirow{3}{*}{19} & \multirow{3}{*}{ Bagian depan } & 0,33 & Memindahkan bahan dari bengkel & & $\sqrt{ }$ & \\
\hline & & 0,11 & Mengambil bahan dan alat & & & $\sqrt{ }$ \\
\hline & & 13 & Perakitan & $\sqrt{ }$ & & \\
\hline \multirow{2}{*}{20} & \multirow{2}{*}{$\begin{array}{l}\text { Silang jendela } \\
\text { (16) }\end{array}$} & 0,06 & Kelebihan potong bahan (Salah proses) & & $\sqrt{ }$ & \\
\hline & & 60 & Perakitan & $\sqrt{ }$ & & \\
\hline \multirow{2}{*}{21} & \multirow{2}{*}{$\begin{array}{l}\text { Jendela atas } \\
\text { (2) }\end{array}$} & 5 & Menunggu proses pengeringan & & $\sqrt{ }$ & \\
\hline & & 12 & Perakitan & $\sqrt{ }$ & & \\
\hline \multirow{2}{*}{22} & \multirow{2}{*}{$\begin{array}{l}\text { Lis jendela } \\
\text { (16) }\end{array}$} & 0,1 & Mengambil bahan dan alat & & & $\sqrt{ }$ \\
\hline & & 60 & Perakitan & $\sqrt{ }$ & & \\
\hline \multirow{2}{*}{23} & \multirow{2}{*}{ Lantai dasar } & 1,11 & Mengambil bahan & & & $\sqrt{ }$ \\
\hline & & 12 & Perakitan & $\sqrt{ }$ & & \\
\hline \multirow{3}{*}{24} & \multirow{3}{*}{$\begin{array}{l}\text { Genteng } \\
\text { depan }\end{array}$} & 0,06 & Mengambil bahan & & & $\sqrt{ }$ \\
\hline & & 0,08 & Proses pemotongan ulang & & $\sqrt{ }$ & \\
\hline & & 60 & Perakitan & $\sqrt{ }$ & & \\
\hline \multirow{4}{*}{25} & \multirow{4}{*}{$\begin{array}{l}\text { Genteng } \\
\text { belakang }\end{array}$} & 30 & Menunggu genteng depan kering & & $\sqrt{ }$ & \\
\hline & & 0,08 & Mengambil bahan & & & $\sqrt{ }$ \\
\hline & & 0,06 & Proses pemotongan ulang & & $\sqrt{ }$ & \\
\hline & & 55 & Perakitan & $\sqrt{ }$ & & \\
\hline \multirow{4}{*}{26} & \multirow{4}{*}{ Genteng kiri } & 30 & Menunggu genteng belakang kering & & $\sqrt{ }$ & \\
\hline & & 0,1 & Mengambil bahan & & & $\sqrt{ }$ \\
\hline & & 0,06 & Proses pemotongan ulang & & $\sqrt{ }$ & \\
\hline & & 32 & Perakitan & $\sqrt{ }$ & & \\
\hline \multirow{4}{*}{27} & \multirow{4}{*}{$\begin{array}{c}\text { Genteng } \\
\text { kanan }\end{array}$} & 30 & Menunggu genteng belakang kering & & $\sqrt{ }$ & \\
\hline & & 0,1 & Mengambil bahan & & & $\sqrt{ }$ \\
\hline & & 0,08 & Proses pemotongan ulang & & $\sqrt{ }$ & \\
\hline & & 33 & Perakitan & $\sqrt{ }$ & & \\
\hline
\end{tabular}

(Ket:VA=Value Added, $\mathrm{NVA}=$ Non Value Added, NVAN=Non Value Added Necessary)

Setelah dilakukan identifikasi waste pada Tabel 2 berdasarkan klasifikasi VA, NVA dan NVAN pada proses pengamplasan, terlihat bahwa terjadi 30 waste pada klasifikasi NVA dengan persentasi waktu $19,2 \%$, terjadi 18 waste pada klasifikasi NVAN dengan persentasi waktu 0,6\%. Kemudian dari masingmasing klasifikasi tersebut dapat dihitung persentasi waktu kerjanya. Rekapitulasi persentasi VA, NVA dan NVAN pada proses perakitan pola dapat dilihat pada Tabel 3.

Tabel 3. Rekapitulasi Persentasi VA, NVA, NVAN Proses Perakitan

\begin{tabular}{cccccc}
\hline No & Klasifikasi & Persentasi (\%) & Klasifikasi & Persentasi (\%) & Waktu (Menit) \\
\hline 1 & VA & 30 & 38,5 & 563,3 & 80,2 \\
\hline 2 & NVA & 30 & 38,5 & 134,47 & 19,2 \\
\hline 3 & NVAN & 18 & 23 & 4,23 & 0,6 \\
\hline & Total & $\mathbf{7 8}$ & & $\mathbf{7 0 2}$ & \\
\hline
\end{tabular}

Berdasarkan kondisi aktual CV.RB tersebut maka dapat disimpulkan beberapa jenis pemborosan yang terjadi di CV.RB, antara lain: inventory, processing, motion dan waiting. Langkah selanjutnya adalah membuat fishbone diagram, hal ini untuk mengetahui faktor-faktor penyebab masalah yang sangat berpengaruh pada penelitian ini. 


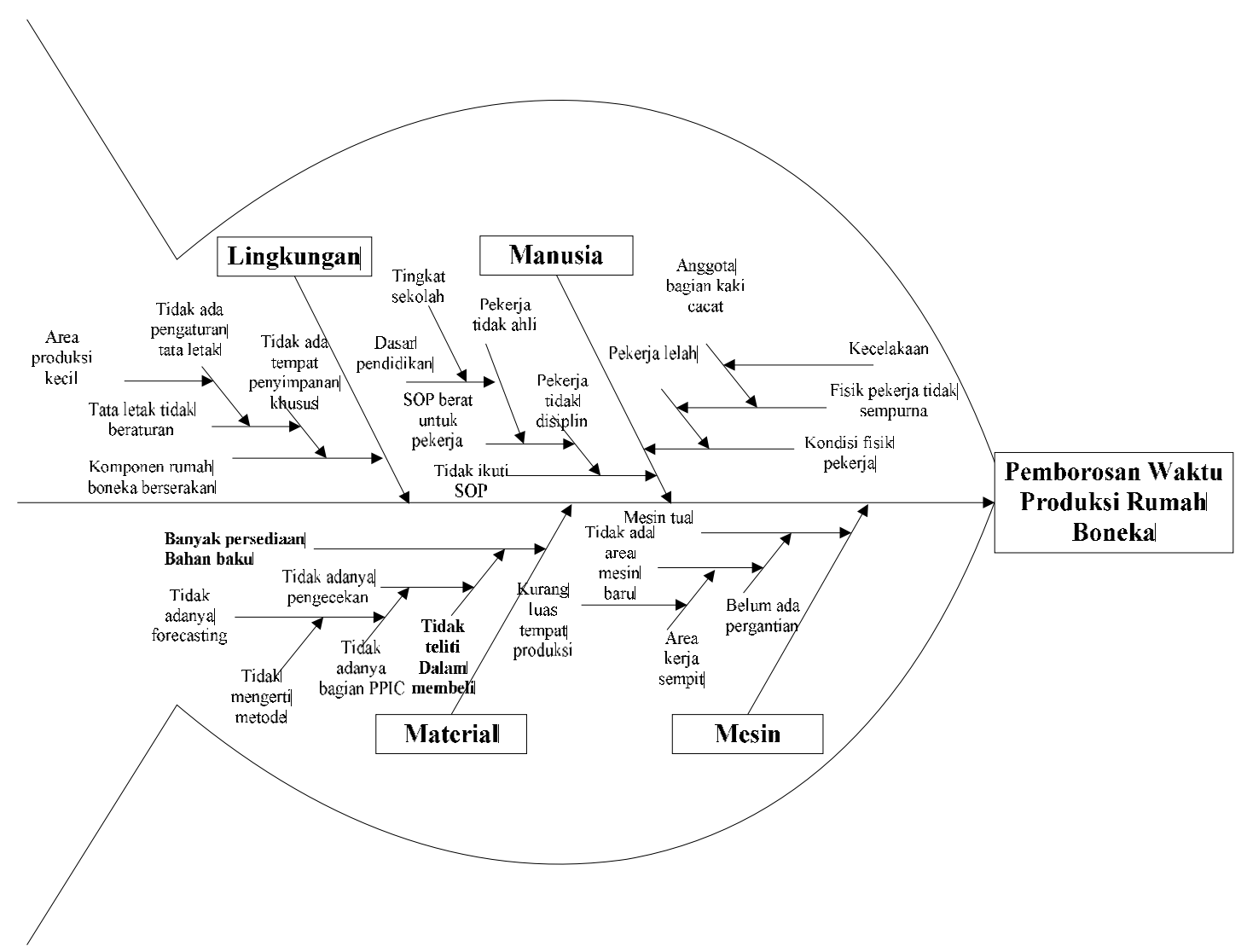

Gambar 2. Fishbone Diagram Pemborosan Waktu Produksi Rumah Boneka

Berdasarkan Gambar 2 tersebut terdapat faktor-faktor penyebab terjadinya pemborosan waktu produksi diantaranya yaitu: manusia, material, mesin dan lingkungan. Setiap kategori mempunyai sebab-sebab yang perlu diuraikan. Pada kategori manusia, pekerja yang melakukan aktivitas pembuatan rumah boneka di CV.RB hanya sedikit yang ahli dalam produksi rumah boneka tersebut. Pada tingkat kehadiran, pekerja juga sering tidak tepat waktu dalam melakukan pekerjaannya. Kategori material, material yang digunakan untuk memproduksi rumah boneka tidak semua material tersedia di gudang, apabila ada pesanan dari pelanggan, maka CV.RB langsung melakukan order material dari supplier dan apabila barang sudah di tempat maka pekerja baru bisa melakukan aktivitasnya.

Pada kategori mesin yaitu mesin yang digunakan pada proses produksi rumah boneka sudah tua, mengakibatkan kurang optimalnya proses pemotongan pada komponen rumah boneka. Saat CV.RB mendapatkan banyak pesanan, pekerja harus antri untuk menggunakan mesin karena terbatasnya mesin yang dimiliki oleh CV.RB. Akar penyebab masalah yang terakhir yaitu kurangnya tempat penyimpanan di gudang, dan sempitnya bengkel. Hal ini mengakibatkan sulitnya para pekerja yang memiliki kecacatan fisik untuk masuk ke dalam bengkel dengan menggunakan kursi roda.

Berdasarkan keempat faktor tersebut nantinya akan dijabarkan secara rinci melalui analisis 5 why. Analisis 5 why berguna untuk menemukan masalah yang sangat berpengaruh yang menyebabkan masalah pada produksi ini. Penggunaan 5 why pada penelitian dengan cara menjabarkan akar masalah sesuai faktor dari fishbone diagram dengan pertanyaan "mengapa" sampai mendapatkan akar paling mendasar dari permasalahan yang terdapat pada CV. RB. Uraian 5 why pada masalah pemborosan waktu produksi ini dapat dilihat pada Gambar 2. 
Tabel 4. Usulan Perbaikan Dengan Metode 5W1H

\begin{tabular}{cccccc}
\hline $\begin{array}{c}\text { Jenis } \\
\text { Pemborosan } \\
(\text { What })\end{array}$ & $\begin{array}{c}\text { Sumber } \\
\text { Pemborosan } \\
(\text { Where })\end{array}$ & $\begin{array}{c}\text { Penanggung } \\
\text { Jawab }(\text { Who })\end{array}$ & $\begin{array}{c}\text { Waktu } \\
\text { Terjadinya } \\
(\text { When })\end{array}$ & Penyebab $($ Why $)$ & $\begin{array}{c}\text { Saran Perbaikan } \\
(\text { How })\end{array}$ \\
\hline Motion & $\begin{array}{c}\text { Stasiun kerja } \\
\text { perakitan pola }\end{array}$ & Pekerja rakit & $\begin{array}{c}\text { Selama proses } \\
\text { perakitan kerja } \\
\text { berlangsung }\end{array}$ & $\begin{array}{c}\text { Tidak adanya tempat } \\
\text { penyimpanan bahan } \\
\text { yang khusus }\end{array}$ & $\begin{array}{c}\text { Menyediakan tempat } \\
\text { penyimpanan bahan }\end{array}$ \\
\hline Waiting (4) & $\begin{array}{c}\text { Stasiun kerja } \\
\text { perakitan pola }\end{array}$ & Pekerja rakit & $\begin{array}{c}\text { Selama proses } \\
\text { perakitan kerja } \\
\text { berlangsung }\end{array}$ & $\begin{array}{c}\text { Keadaan cuaca yang } \\
\text { tidak mendukung } \\
\text { dan juga tidak ada } \\
\text { alat pengering saat } \\
\text { cuaca tidak bagus }\end{array}$ & $\begin{array}{c}\text { Memperbanyak } \\
\text { mesin pengeringan, } \\
\text { peperti kipas angina } \\
\text { perakitan kerja }\end{array}$ \\
\hline
\end{tabular}

\section{SIMPULAN}

Berdasarkan pengamatan di lantai produksi terdapat pemborosan waktu pada proses pengerjaan perakitan pola. Hal ini disebabkan oleh beberapa faktor yaitu: material, manusia, lingkungan dan mesin. Pada faktor material hal ini disebabkan oleh kurangnya pengetahuan tentang peramalan dalam pembelian material, hal ini berdampak pada lamanya waktu produksi disebabkan lamanya waktu mencari material bahan baku produksi. Pada faktor manusia yaitu dikarenakan kurang disiplinnya pekerja dalam melakukan kegiatannya. Pada faktor lingkungan yaitu kurangnya penataan stasiun kerja dan bengkel. Pada faktor mesin disebabkan mesin yang digunakan sudah tua, hal ini mengakibatkan lamanya pekerja dalam melakukan kegiatannya.

Beberapa pemborosan waktu produksi proses perakitan pola yang mengakibatkan lamanya kegiatan. pemborosan yang terdapat pada bagian perakitan ini yaitu motion dan waiting. Motion (gerakan) yang dilakukan pada proses ini yaitu mengambil dan mengembalikan alat kerja ke stasiun kerja yang daerahnya berjauhan dari stasiun kerja sebelumnya. Pada pemborosan waiting terjadi kegiatan menunggu agar cepat kering yang digunakan untuk menggabungan 2 buah komponen. Berdasarkan analisis tersebut maka dilakukan usulan perbaikan sebagai berikut yaitu menyediakan tempat penyimpanan bahan baku dan alat, kemudian memperbanyak mesin pengering agar lem yang digunakan pada proses perakitan dapat kering dengan cepat.

\section{DAFTAR PUSTAKA}

[1] Badan Pusat Statistic. (2015). Profil Industri Mikro dan kecil. Retrieved from http://www.bps.go.id.

[2] Rahani, A. R., \& Al-Ashraf, M. (2012). Production flow analysis through value stream mapping: a lean manufacturing process case study. Procedia Engineering, 41, 1727-1734.

[3] Wanitwattanakosol, J., \& Sopadang, A. (2012). A framework for implementing lean manufacturing system in small and medium enterprises. In Applied Mechanics and Materials (Vol. 110, pp. 39974003). Trans Tech Publications.

[4] Gasperz, V. (2011). Metode Analisis Untuk Peningkatan Kualitas. Jakarta: PT. Gramedia Pustaka Utama. 